\title{
Internuclear Bridging of Erythroid Precursors in the Peripheral Blood Smear of a Patient with Primary Myelofibrosis
}

\author{
Primer Miyelofibroz Tanılı Bir Hastanın Çevre Kanı Yaymasında Eritroid Öncüllerin \\ Nükleuslar Arası Köprüleşmesi
}

Roger K. Schindhelm¹, Marije M. van Santen², Arie C. van der Spek³

${ }^{1}$ Northwest Clinics, Department of Clinical Chemistry, Hematology and Immunology, Den Helder, the Netherlands

2Symbiant Pathology Expert Center, Alkmaar, the Netherlands

${ }^{3}$ Northwest Clinics, Department of Internal Medicine, Den Helder, the Netherlands

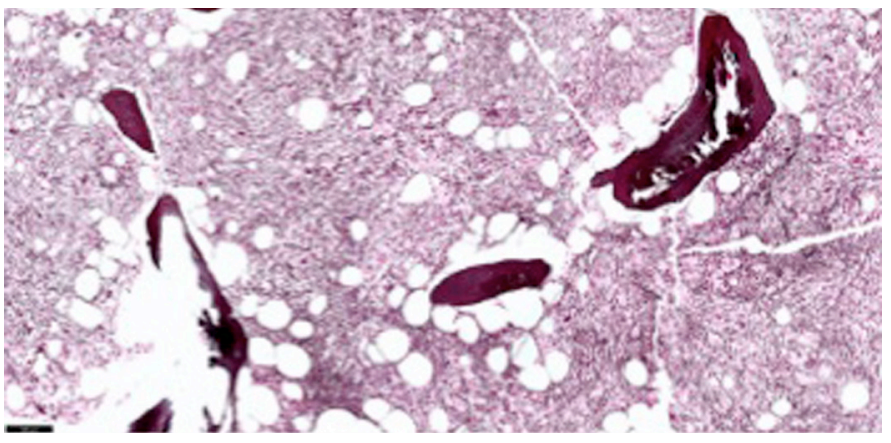

Figure 1. Bone marrow biopsy showing marked increase in reticulin fibers, especially in the areas of megakaryocyte clustering (Gomori, 10x).

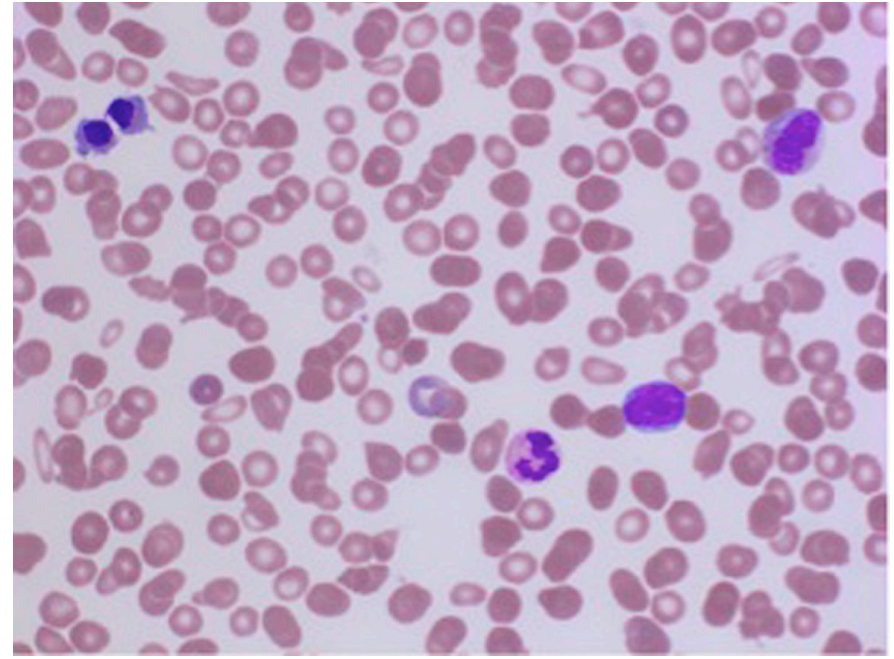

Figure 2. Blood smear demonstrating teardrop cells, erythroid precursor with internuclear bridging, and one blast cell (MayGrünwald-Giemsa, 50x).
An 84-year-old male diagnosed with primary myelofibrosis based on WHO grade 2-3 fibrosis (Figure 1) and the presence of the JAK2-V617F mutation was treated with supportive care. During 2 years of follow-up, his hemoglobin level was maintained at approximately $6.5 \mathrm{mmol} / \mathrm{L}$ and platelet count declined from $128 \times 109 / \mathrm{L}$ at presentation to $50 \times 10^{9} / \mathrm{L}$. White blood cells did not exceed $12.0 \times 10^{9} / \mathrm{L}$, while the fraction of blast cells increased to $10 \%$. Elevated levels of teardrop cells were observed and the nucleated red blood cell count gradually increased from non-detectable to $2.4 \times 10^{12} / \mathrm{L}$. Recent peripheral blood smears showed bi- and tri-nucleated red blood cells, and even more notably, erythroid precursors with internuclear chromatin and cytoplasmic bridging (Figures 2 and 3). In concurrence with laboratory findings, physical examination revealed progressive splenomegaly $(8 \mathrm{~cm}$ palpable below the rib margin) and weight loss. Erythroid precursors with internuclear bridging in a blood smear is a rare morphological finding and is considered a diagnostic morphologic feature in patients with congenital dyserythropoietic anemia type I and a morphological manifestation of dyserythropoiesis in

- Copyright 2017 by Turkish Society of Hematology

Turkish Journal of Hematology, Published by Galenos Publishing House

口ifing for Correspondence/Yazışma Adresi: Roger K. SCHINDHELM Ph.D. 


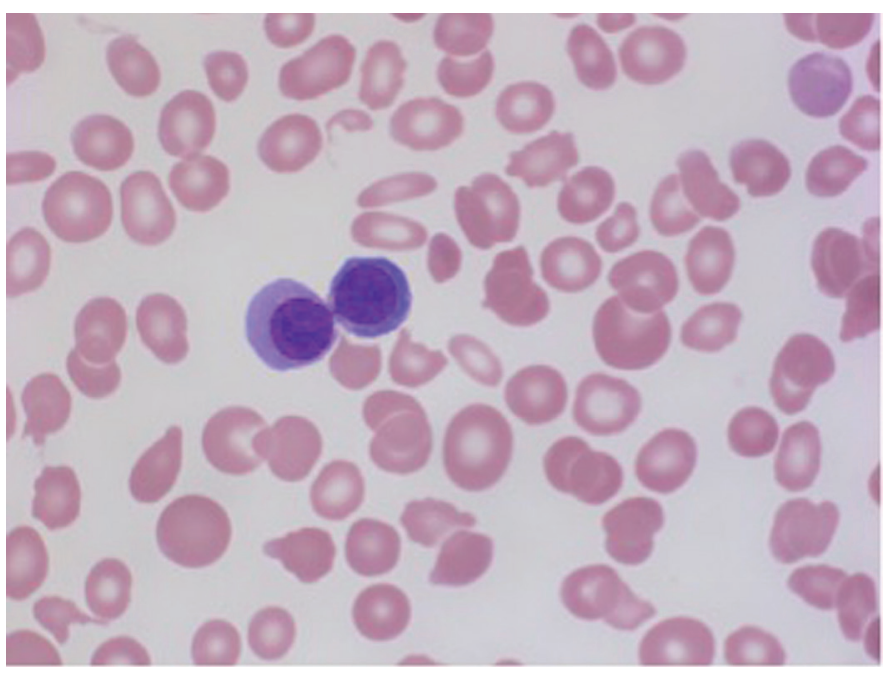

Figure 3. Blood smear demonstrating erythroid precursor with internuclear and cytoplasmic bridging (May-Grünwald-Giemsa, $100 \mathrm{x})$. patients with myelodysplastic syndrome [1,2]. In patients with myeloproliferative neoplasms, erythroid precursors' internuclear bridging may indicate the transition to a more aggressive phase.

Keywords: Primary myelofibrosis, Internuclear bridging, Erythrocytes

Anahtar Sözcükler: Primer miyelofibroz, Nükleuslar arası köprüleşme, Eritrositler

Conflict of Interest: The authors of this paper have no conflicts of interest, including specific financial interests, relationships, and/or affiliations relevant to the subject matter or materials included.

\section{References}

1. Iolascon A, Esposito MR, Russo R. Clinical aspects and pathogenesis of congenital dyserythropoietic anemias: from morphology to molecular approach. Haematologica 2012;97:1786-1794.

2. Head DR, Kopecky K, Bennett JM, Grenier K, Morrison FS, Miller KB, Grever MR. Pathogenetic implications of internuclear bridging in myelodysplastic syndrome. An Eastern Cooperative Oncology Group/Southwest Oncology Group Cooperative Study. Cancer 1989;64:2199-2202. 